\title{
WAGNER AND SHAKESPEARE
}

\author{
By EDGAR ISTEL
}

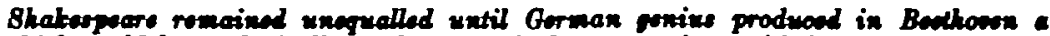
bring wiok oould be analogically axplained only by comporion with him.

Rrcrind Wagren
\end{abstract}

$\mathbf{I}^{\mathrm{N}}$

N a letter to his friend Mrs. Eliza Wille, dated September 9, 1864, Wagier wrote: "I remember a dream of my early youth, when I dreamt that Shakespeare was alive, and that I met him and spoke to him, actually, in the flesh; the impression this dream left on me was indelible, and eventually grew into a longing to see Beethoven, too (who also had died long before)." This longing of Wagner's for Beethoven (who died when Wagner was about 14 years old) crystallized into the fantastic novelette "A Pilgrimage to Beethoven," written in 1840, when Wagner was twenty-seven years old. In this novelette the youthful musical dramatist attributes to his musical ideal, artistic aims not very greatly differing from those which Wagner himself strove to attain in his future artistic work. How intimately, however, these aims were attached to the names of Shakespeare and Beethoven, is evident from the answer Wagner let his imaginary Beethoven give the art disciple: "If anyone did write a truly musical drama, he would be looked upon as a fool, and he would indeed be a fool for not keeping it to bimself, but setting it before the world."

"And what would one have to do," I1 asked excitedly, "to create such a musical drama?"

"Do as Shakespeare did, when he wrote his plays," was the almost sharp reply.

Thus, even in early youth, the name of the greatest dramatic genius of all ages was coupled, in Wagner's mind, with that of the magnificent symphonist. The influence this had on Wagner's mental development was so great, that it will be interesting to follow its various stages through his life-history.

Apparently at the suggestion of his uncle, Adolf Wagner,? young Wagner had very early been interested in the great Briton.

"This "I" of course means Wegner himself.

Adolf Wagner had published a German tranalation of Auguatine Scottowe's

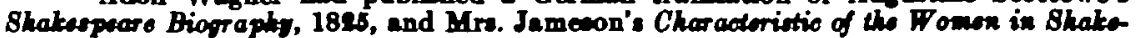
speare's Ploye, 1884. 
It is a characteristic feature, that he immediately wished to read his works in the original. He himself relates how he studied English, "only to read Shakespeare and thoroughly master him." He made an attempt at a metrical translation of Romeo's monologue; unfortunately, the manuscript has been lost. "I soon dropped English again, but Shakespeare ever remained my model." The offspring of this youthful enthusiasm for Shakespeare was indeed of a very grotesque nature; the "subject of the crime" then perpetrated (as Wagner himself calls it, in his autobiography "My Life"), was a long tragedy, "Leubald," the manuscript of which has recently been rediscovered.1 According to this latter, the statements which Wagner made from memory touching this piece, in his autobiographical papers, are frequently erroneous. Wagner's recollection, however, that this drama was completely based on Shakespeare, is correct: Hamlet, Macbeth and Lear were, as Wagner says, its spiritual godfathers. "The story is practically a mere variation of Hamlet, with this difference, that my hero is driven by the apparition of the spirit of his father, murdered under similar circumstances, and by his call for revenge, to such violent deeds, that he finally goes mad after a series of murders. In temperament a mirture of Hamlet and Percy Hotspur, Leubald has vowed to his father's spirit to "wipe the whole clan of the Roderichs from the face of the earth," etc." But not only Hamlet, Macbeth and King Lear, but other of Shakespeare's plays (Wagner himself mentions Richard III), in particular Romeo and Juliet and Coriolanus, had influenced young Wagner. Besides the outline of the story, the description given by the spirit of his death, and a great "To be or not to be" monologue by Leubald, point at Hamlet; the Lorenzo-like character of a hermit, at Romeo and Juliet; a scene of witches, at Macbeth; the description of battles, at Coriolanus; in short, as Wagner himself testifies, he left no means unemployed to fit out his drama with the richest effects.

A chief ingredient, however, for my poetical work I borrowed from the pathos and humor of Shatespeare's forceful opeech. The daring of my bombartic and high-flown language naturally atartled and surprised my uncle .... To me there remained ..... curious inner solace for the want of appreciation I met with; I knew, what no one else could know, that my work could be properly judged only after it had been set to music, which I decided to write, and which I intend to produce very soon.

In the pomenion of the heirs of Mre. Burrel, London. (CF. Burrel's $R$. Wagmer. London, 1905, and Kepp's edition of Wegnet's mitinge by Hease, Vol. 6, where dotailed extracte are given.)

2Cf. the full detail of contents in "Mr Lrs," p. 85 af ces. 
In this connection certain points are of peculiar importance; here the drama $d$ la Shakespeare is already blended with a reminiscence of Beethoven; the name Adelaide ("whose fond refrain appeared to me the symbol of all love-cries"), and his fondness for alliteration ("Woher um mich dies wonnigliche Wehen" is the most remarkable example), this latter obviously born of musical reasons. In describing the awakening of his sense for music, Wagner then tells of his first acquaintance with the masterpieces of musical art (above all Beethoven, Weber and Mozart). Beethoven's "Egmont," this play set to music, which may well have served him as a model for his "Leubald" (as regards the musical part), had chiefly influenced him. The death of Beethoven, which made a deep impression on him, produced an "image of most exalted, superhuman originality, with which nothing else could bear comparison. This image blended in me with that of Shakespeare; I met, saw and spoke to both in ecstatic dreams; when I awoke, I was bathed in tears" - in a word, a renewed confirmation of the vision already mentioned. Eventually, Beethoven's Egmont music so enraptured him that, as he relates,

I could not think of launching my finished drame without a similar music. I was quite confident of being able to write this music by myself, but nevertheless doemed it advisable first to inform myaelf on some principal rules of thorough-bass . . . . This study, however, did not bear as early fruit as I had expected; the difficulties encountered allured and fascinated me; I determined to become a musician.

Thus the 15-year-old boy became a musician in emulation of Beethoven only from a desire to write the music to a play formed on a Shakespearean model, and this development is so characteristic for Wagner, that the writer of "Parsifal" could say of himself:

I prudently intend to adventure into music only so far as I may hope to realize poetical intentions by its aid.

We thus have the following facts: Shakespeare taught Wagner, the dramatist, and Beethoven's music was absorbed by him only in $s 0$ far as he felt it adequate for the musical expression of Shakespearean situations. Immature as these dramatico-musical endeavors may appear, we may discern therein the germ from which sprang the towering growth of Wagner's later art. At first, however, Wagner shared the same fate as Schiller, who, in later years, could say of the youthful author of the "Robbers" that one could see from the extravagances rather than the beauties of the piece, how the author doted on his Shakespeare. 
Wagner entered into still closer relations to Shakespeare than by this monstrous attempt of his youth with his opers "Das Liebesverbot" (or, as it was called at its production, by order of the censor, "The Novice of Palermo"), written in 1834 and completed with music early in 1836. This opera, which, under Wagner's own direction, was produced only once in Magdeburg (on March 29, 1896), has never been printed, and can be studied only in the manuscript score, which is carefully guarded under lock and key in the National Museum at Munich. I am indebted to the kindness of the late Director, Dr. Stegmann, for opportunity to report on this work. ${ }^{1}$

Undoubtedly, in later years the mature master felt deeply that this "curious work of his youth," which Wagner himself calls a "wildly-revolutionary, voluptuously frivolous reconstruction of Shakespeare's first drama Measure for Measure," is also at the same time a sin against Shakespeare. The 24 -year-old opera writer had sacked, plundered Shakespeare more than he had studied him, but, in doing so, had shown so eminent a staging sense, that we cannot regard his daring enterprise without a certain amount of sympathy.?

When Wagner made "Das Liebesverbot" out of "Measure for Measure," he had almost entirely lost bis former respect for Shakespeare and Beethoven.

I took the idea for "Das Liebesverbot" from Shakespeare's "Measure for Measure," only with the difference that I discarded the serious vein, and remodeled it after neo-European taste; free, open voluptuounness won, by its own force, the victory over Puritan hypocriny. The music had a formative influence on matter and arrangement, and this music was the reflection of the influence of modern French and (as regards the melody) of Italian opera on my sensuously excited sensibility. If the composition were to be compared with that of "Die Feen,"' one would hardly understand how, within so brief a period, so surprising a change of tendencies could occur; the reconciliation of these two was to be the tesk of my artistic development.

From this last sentence it is evident, how very important this transitional work was for Wagner's further artistic course-a link which it would be as impossible to omit from his development

1Cy. my exteneive atudy on this work, with numerous extracts from the muric, publiahed in "Die Murik," VIII, 192, Space allow me to diecule only the drameturgical side of the matter.

'A unique copy of the libretto, revieed by Tagner, is to be found in the Library of Congrea in Wahlington. B. Hirzel wrote on this in "Gemmelbinde der I. M. G.," XIII, 8.

'Pragner's fint opera, never produced during his lifetime, written in the style of the German romanticints Weber and Marachner, worde after Gossi"s "La donne erpente." 
as (say) the "Robbers" from that of Schiller, or "Werther" from Goethe's life.

In wise recognition of one demand of the operatic stage which is, unfortunately, not always sufficiently considered,-namely, to employ as few characters as possible and mould the play in the simplest form possible-Wagner reduced the number of persons (22) in the play of the English writer to eractly one-half (11), whereby he gained greatly for the musical setting. Luxio and Claudio, Isabella and Matiana, correspond to the like-named personages of Shakespeare, Antonio and Angelo to the two unnamed noblemen of Shakespeare; Angelo, the name of the governor, has been changed to the German Friedrich; the English constable "Elbow" is transformed into an Italian "Brighello." (This name indicates in Italian melodrama, to which Gozzi's fairy-tale "La donna serpente"-used by Wagner as a model-partly belongs, the role of a sly servant, whose costume was white with green ribbons.) The procuress, Mrs. Overdone, has become a less obtrusive wine-shop owner Danieli, whose man-servant no longer bears the proud name of Pompey, but that of "Pontius Pilate," which, under the circumstances, sounds equally funny. A wholly new creation is the maid-servant Dorella, who-in herself a subordinate personage only-becomes, in consequence of her relations to the constable Brighello, a very important factor in the play. Besides the change of locality from Vienna to Palermo, the most important alteration in the piece is the omission of the sovereign, Duke Vincentio, who, in Shakespeare a chief, if not the chief, personage, was discarded by Wagner; the "King" mentioned in the opera does not appear as an acting person. Here Wagner expunged a peculiar beauty of the Shakespeare play, but, at the same time, he showed an instinct for opera work whjch already suggests the "lion's claw" which is more distinctly discernible in "Rienzi." His object Wagner states in his "Mittheilungen an meine Freunde":

It was Isabella who inspired me, emerging as a novice from the nunnery to pray the hard-hearted governor for mercy towards her brother, who was condemned by a Draconic law to death for the crime of a love-alliance with a girl that, though forbidden, was blessed by nature. Isabella's chaste soul finds such powerful arguments before the callous judge for excusing the crime in question, and her love enables her to present these arguments with such overpowering passion, that the severe censor of morals himself is seized with a passion for this admirable woman. This swiftly kindled flame is revealed by his promise to pardon the brother in return for the sister's love. Indignant at such a suggestion, Isabella takes refuge in a scheme to expose the hypocrite and save 
her brother. The governor, to whom she feigns a willingness to yield to his desire, nevertheless deems it proper not to keep his promise of pardon, 8 as not to sacrifice his judicial conscience to an unlawful love. Shakespeare settles the resultant conflicts by making the prince (who has until then been a hidden observer) return into public life; his decision is of a serious character, based on the "measure for messure" of the judge. I, on the contrary, untie the lnot vithout the prince, by the aid of a revolution. I ahifted the acene of the play to the capital of Sicily, that I might avail myself of the inflammable southern blood; I let the governor, a puritanical German, forbid the impending carnival; a desperate young man, who has fallen in love with Isabelle, incites the mob to put on their manks and get their knives ready: "Who in our revel takes no part, for him the steel to cleave his heart!" The governor, induced by Irabella to come, himelf maked, to the rendex-vous, is recognized and mocked; the brother is reacued at the last moment before his execution; Isabella resigns as a novice and gives her hand to the wild carnival friend: in a fully masked procession all march of to meet the returning prince, assuming that he will not be so irrational as the governor.

A few passages from the "Mittheilungen" are added in explanation:

The ideas at that time infesting Young Europe, together with the perusal of 'Ardinghello,' aggravated by the strange mood of opposition to German opera into which I had fallen, furniched the fundamental tone for my conception, which, being aimed especially against Puritanical hypocrisy, led to a defient glorification of 'free love.' I sought to realize the werious Shakespearenn subject from this aspect alone; I saw only the gloomy, eustere Governor, himself inflamed by a terribly pasgionate love for the beautiful novice, who, while besecching him to pardon a brother condemned to death for a love-fault, kindles the most baleful pascion in the stern Puritan through infection by the winning warmth of her human emotion. It in no way fell in with my plan to consider that thewe powerful motives were so amply developed in Shakespeare's play only to be thrown with all the greater weight into the scales of justice; my sole aim was to lay bare the sinfulness of hypocrioy and the unnaturalness of ruthless moral censoriouness. So I quite discarded the "measure for measure,' and left the punishment of the hypocrite to avenging love alone. I removed the cene of the play from a mythical Vienna to the capital of fervent Sicily, where a German Governor, acandalized by the - to him -incomprehensible freedom of morals in the populace, attempts to carry out a Puritanical reform, whereby he meets with sore defent. Probably La Muette de Portioi contributed something to this end; memories of I Vespri Biciliani may have done their part; when I consider that even the gentle Sicilian Bellini figures among the factors in this composition, I really have to amile over the strange quid pro quo into which the most singular misunderstending lead.

Despite all weakness in the lines, it is marvellous in how skillful a manner Wagner simplified Shakespeare's complicated plot with respect to the stage presentation, as well; the five acts of the 
English comedy are reduced to two, and these are limited to a minimum of changes of scene. Act I plays, to begin with, in a suburb, then in the convent courtyard, and finally in the courtroom. Act II-the symmetry is notewortby-likewise displays three scenes; the prison garden, a room in Friedrich's palace, and the "End of the Corso."

In the score is found the customary old lay-out in numbers. As No. 1, we have the Overture, an extremely stirring and fiery piece. The orchestral factors which Wagner already utilizes here, are quite abundant - two flutes, a piccolo, two oboes, two clarinets, two bassoons (later a third bassoon is used occasionally, or, in its stead, a double-bassoon), four horns, two trumpets, two kettledrums, castanets, tambourine, triangle, bass drum and cymbals, three trombones, an ophicleide, and strings. Besides these there appear on the stage, in the course of the opera, a bell, and (at the close) a formidable "banda militare" of two piccolos, one clarinet in $E$, two clarinets in $D$, two clarinets in $C$, two valve-trumpets in $D$, four trumpets in $D$, four horns in $D$, four bassoons, three trombones (alto, tenor, bass), an ophicleide, triangle, side-drum, bass drum, and cymbals. Wagner relates that, as "characteristic for the treatment of his tone-coloring, the conductor of a military band, who, be it said, was greatly pleased with the job, thought it necessary to give me some well-meant advice for the handling of the Turkish drum in future works."

After a four-measure trill by castanets, tambourine and triangle, the overture begins directly with the lively theme taken from the introduction to the Carnival Song:

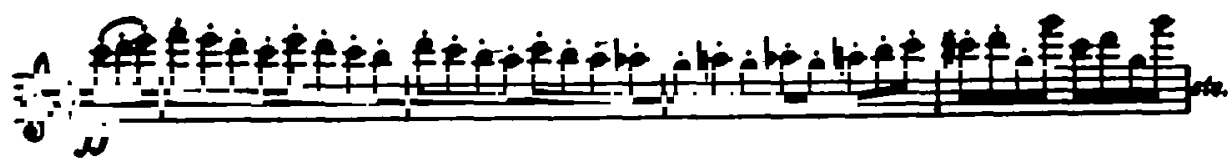

All at once there emerges, as if from another world, a new, unbending motive - that of the Liobesoerbot (prohibition of love):

(All strings, clarinets, bassoon, trombones and ophicleide, in unison.)

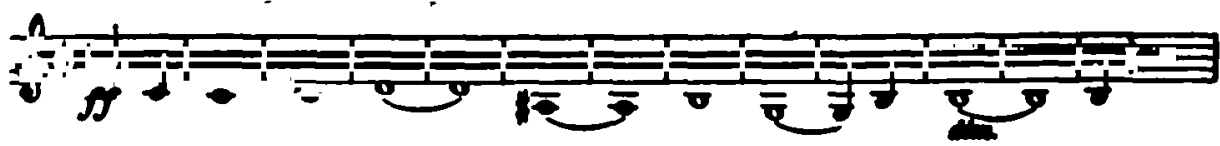

It was assuredly a stroke of genius to contrast this sinister theme in its inflexible severity with the wanton gayety of the southern Carnival Song relntering immediately after. In these 
two themes the dramatic concept of the work is, so to speak, exhausted; in the one, sensuous delight, in the other, sombre zealotiom. The essence of the drama, antagonism, was instinctively grasped by the young master in a truly surprising manner. This antagonism penetrates not only the exposition, but the entire overture, whose singular development-section is devoted to the conflict between the two principles, and is peculiarly fascinating in its contrapuntal evolution of the love-prohibition theme, which in most cases appears in abbreviated form.

As the third principal theme of the overture, which now goes over from Allegro vivace to Allegro con fuoco, we find the following leading-motive:

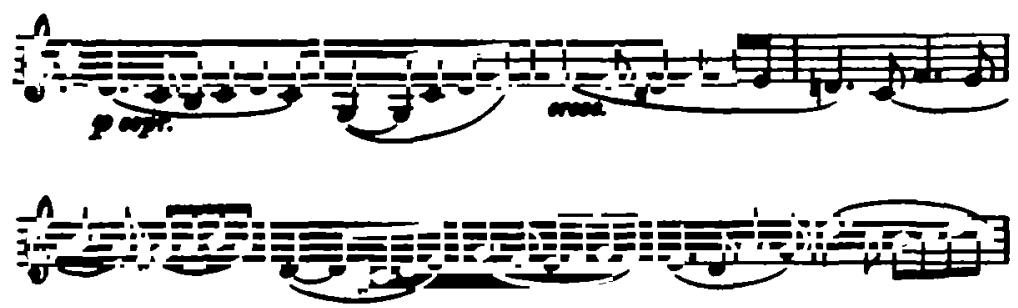

The signification of this theme is first revealed in the great scene between Friedrich and Isabella in Act I. It is the theme,of Friedrich's love-frenzy, which enters frequently in the further course of the opera; bere, however, it indicates the conflict between sensuality and puritanism, as decided in favor of the former.

But the miscreant is now fearsomely confronted by his own "love-prohibition," and his frenzy of passion dies down to a whine. The Carnival Song again enters alluringly, but has a hard struggle to maintain its ground against the prohibition theme (development).

Such combinations show, at all events, that the frivolous levity which Wagner himself always held to be characteristic of this score, was materially toned down by his thorough training. -Now follows the repetition of the principal section, succeeded by a Presto (a fanfare by the brass) announcing the King's arrival. At the close the Carnival Song once more appears, and victoriously holds the field. This overture gives a good idea of the musical style of the work.

For Wagner, however, still another change of style is impending; he writes: "I now almost wholly renounced my Liebesourbot; I felt that I could no longer respect myself as its composer. All the more independently did I follow my true artistic belief while continuing the composition of Riensi." 
This Riensi (based upon Bulwer-Lytton's novel, "Cola Riensi, the Last of the Tribunes," and begun by Wagner in the summer of 1857), while musically still wholly under the influence of the French grand opera of Spontini, Auber, Meyerbeer and Halevy, nevertheless shows, dramatically, the power, the glowing inspiration of genius, that could have been revived in Wagner only by a renewed study of Shakespeare. The very first scene of the opera is suggestive of Shakespeare. The rivalry between the clans of Colonna and Orsini must have reminded Wagner of the hostile Veronese families in "Romeo and Juliet," and so he needed only to take over the masterly exposition of the Shakespearean drama in order to obtain an effective opening for his opera. Assuredly, however, Wagner was already no slavish imitator, but a worthy disciple of his great dramatic teacher. Indeed, the subject-matter itself is a direct challenge to similar treatment; in both cases, headstrong noblemen, and also a prominent personage who exhorts them to keep the peace and at first allays the partisan conflict.

Rebellious subjects, enemies to peace,

Profaners of this neighbour-stained steel,

Will they not hear?-What, ho! you men, you beasts!

So says Escalus in Shakespeare, and Wagner's Riensi quite similarly exclaims:

This is your handiwork! Thereby I know you!

As tender youths ye immolate our brethren,

And ye would rob our sisters of their honour!

What crimes are left for ye to perpetrate?

In more than one other passage of Wagner's Rienzi one may note a trace of Shakespeare's historical drama. And it is precisely when we compare the two operas of the revolution, Auber's $L a$ Muette de Portici and Rienzi, that Wagner's tremendous dramatic superiority, nurtured on Shakespeare, is borne in upon us. There is no particular sense in seeking after disconnected reminiscences. This has already been attempted with more or less success in the case of Wagner's later works, in tracing parallelisms with Shakespeare. Whoever cares to delve into such minutix, should peruse a laborious little essay on "Shakespeare und Wagner, Zusammenhange, Vergleichungen, Parallelen" by Meinck (Liegnitz) in the 39th annual issue of the "Bayreuther Blatter" (p. 120 et seq.). I regret my inability, by reason of artistic scruples, to join in this sort of research-work; the decisive factor is not the uords, which 
are often a mere fugitive echo, but the spirit, and therefore, speaking in general terms, we may say that nowhere else did Wagner lean so heavily on Shakespeare as in the Liobesoerbot and Rionsi. Thereafter he only "studied," no longer "plundered" him; he enjoyed the great Briton's feast of reason and flow of soul without pilfering from him; let us rejoice thereat, without hypercritical intrusion. I really fail to see where The Flying Dutchman, Tannhduser, Lohongrin, Dio Moistorsingor or Parsifal, in their details, reminds one of Shakespeare. Only in two of the later works, Tristan und Isolde and The Ring of the Nibelung, can parallels with Shakespeare be traced unconstrainedly. To be sure, one should not proced as Meinck has done, in contrasting such passages as

KING LEAR (IV, 7), aroaking from alumber: France?

Where have I been? Where am I? Pair daylight?... Am I in with

ThIBTAx (Act III), awaking as from the atupor of death:

Where was I? Where am I? Am I in Cornwall?

KURmeraL: No, no! in Kareol!

Despite the almost literal agreement, this can hardly be taken for an instance of Shakespeare's influence. Shakespeare himself, in a not at all unusual situation, merely puts the most natural words into the mouths of his characters, such as any poet before or after him would have used with scarcely a change.

It is also my opinion that similarities in the stories treated by the two dramatists cannot well be conceived as "influence." Neither is any relation between them shown by the circumstance that the tragic material of Gotterdimmorung is partly to be found in that same tale by Boccaccio which was used by Shakespeare as a comedy entitled "All's Well that Ends Well." And other chance similarities in legendary and mythical features are really of the slightest importance.

Of course, the parallel in the presentation of the Witches in "Macbeth," and of the three Nornen, in Gotterdimmorung, and likewise the three Rhine Daughters, obtrudes itself almost inevitably on every adept; hence there is hardly room for doubt that Wagner first won througb Shakespeare his power for delineating such primitive types. But how prove anything of the kind by detailed instances? "Where feeling fails, you'll never find by questing." ("Wenn ihr's nicht fuhlt, ihr werdet's nie erjagen.") The main question is, did Shakespeare help Wagner to grasp the 
meaning of the fable, to create characters of ultimate type set wholly apart from the "blended types" of reality-imaginary beings of forceful consistency, like those presented by Shakespeare in "Macbeth"? As regards The Ring of the Nibelung we can answer this question, to a certain extent, confidently in the affirmative. True, I cannot point out a single character in Wagner's lifework that can be compared in the remotest degree to the primitive might of. Macbeth or the Lady. Indeed, the profoundest secret of Shakespeare - the way in which, despite all reduction to type, he keeps his characters on the firm ground of innor reality, making them purely typical, but not, like Wagner and Schiller, idealising them at the same time-this secret even a Wagner was impotent to fathom. In order to understand what I mean, first of all contrast the classic pairs of lovers in Shakespeare and WagnerRomeo and Juliet, Tristan and Isolde. Both must wrest the union of their loves from a hostile world; both must suffer death for their love. But how natural, how touchingly human, how wholly artless, is the love of Shakespeare's pair; per contra, what a (one is tempted to say) hysterical, unnatural tension prevails throughout three acts in the relation between Tristan and Isolde. Wagner doubtless learned much for the treatment of his lovetragedy from the great Briton. But what he could not learn, because in later years it was withheld from his morbidly surexcited temperament, was wise moderation even in moments of overmastering emotion. Characteristic of Wagner is a selfdelineation found in his letter to Rockel of Jan. 25, 1854, (that is, from the Tristan period): "I see only, that the normal state of my temperament-in the light of its actual development-is one of exaltation, whereas ordinary tranquillity is its abnormal condition. In truth, I feel quite right only when I am 'beside myself'; then I am entirely self-possessed. - If Goethe was otherwise, I do not envy him for it, neither would I care to exchange with anybody."

On the other hand, Wagner and Shakespeare have something in common which closely unites them-their attachment to the actualities of the stage. Shakespeare was first of all an actor and stage manager, and the fact that his most powerful dramas were evolved in response to the practical requirements of the stage was not at all disadvantageous for these works themselves sub spocie ctornitatio-nay, it rather imparted to them a breath of robust life which in itself, after the lapse of centuries, still suffices to elevate them over all the book-dramas written meanwhile. Wagner himself was at first a child of the living stage, and if thereafter, owing to his unhappy political activities, he was forced to live 
for many years quite out of touch with the theatre, this artistic paralysis caused him the keenest suffering; indeed, it was unquestionably most unfortunate for his later overgrown works. Thus he writes Liszt from Zurich, Dec. 5, 1849: "All the productivity of our poets and composers shows only the Will, not the Power; power, living art, is realized in scenic presentation alone. Believe me, I should be far happier if I were an actor of dramas instead of a dramatic poet and composer." In a similar, but still more positive, strain he writes to Franziska Wagner on July 4, 1850: "No one knows better than I, that the actor is the real artist; what would I not give, could I myself enact the parts of my heroes."

So keen a thinker as Friedrich Nietzsche, who was also for years one of Wagner's intimates, called him the greatest of German scenic artists. Wagner (he sayg) was predestined by nature for an histrionic career; being hindered from fulfilling this destiny, he cultivated-driven thereto, as it were, by unsatisfied longing -his genius for the drama. - I shall not attempt to decide whether this bold hypothesis is correct or the reverse. However, another remark of Nietzsche's (in "Der Fall Wagner," Chap. II) strikes me as more felicitous: "What does Wagner signify in the history of music? The exaltation of the actor in music-an event of capital importance, which furnishes food for reflection, and possibly for apprehension as well."-And again (ibidom): "In Wagner's case, his illusion takes its rise not from tones, but from gestures. For these latter he seeks the fitting tone-speech."

Now, if we raise the question whether Wagner gained anything through study of Shakespeare for his power of musical expression, we find it already answered by Nietzsche's last-quoted assertion. Granting that Wagner's histrionic imagination was fired by Shakespeare (a fact admitting of no doubt, in view of his youthful development), it would appear that, after Beethoven, Shakespeare exercised the most powerful influence on Wagner's musico-dramatical growth. This, to be sure, is quite impossible of proof in detail. We have only a single finished musical work of Wagner's, Das Liebesoorbat, which is directly derived from Shakespeare, and in this instance, as Wagner himself pointed out, the Franco-Italian opera-style made itself felt from the very outset in shaping the dramatic text. So Shakespeare was not the loadstar even for the poem, not to speak of the music. None the less, the musical comedy-scenes in Das Liebesoerbot, conceived in the romantic style, seem to me much more intimately related to Shakespeare's genuine comedies (among which the decidedly cerious "Measure for Measure" can scarcely be reckoned) than 
the somewhat baroque humor of Dis Moistorringer. Whether the heroic character of the Rionsi music was influenced more by the subject or by the study of Shakespeare, is hard to decide. Probably the French operatic prototypes were the chief modifying agency. And if even the sconic influence of Shakespeare is highly problematical in the later works, we surely need take no thought what impreasion he may have made on Wagner's muric.

During Wagner's entire career, however, the study of Shakespeare was of the greatest importance for the totality of his artistic view of life, as we may gather from numerous passages in his writings and letters.

Wagner's enthusiastic devotion to Sbakespeare is shown in Ferdinand Präger's anecdote (in "Wagner wie ich ihn kannte"), according to which Wagner, standing before the Shakespeare monument in Westminster Abbey, sank into a silent ecstasy so long protracted that his wife, growing uneasy, aroused him from his disquieting trance by gently plucking his sleeve; whereupon he burst out in impassioned praises of the poet. In conversation Wagner was fond of expatiating on Shakespeare, especially after reading the dramas aloud, as was his wont while dwelling in Bayreuth. In this connection, Hans von Wolrogen (in "Erinnerungen an Wagner") recorded a significant observation. Wagner, after reading aloud the entire series of the royal dramas, "Hamlet" and "Macbeth," remarked on Hamlet: "That is the crown of the Renaissance; here the inexorable gaze from the stage sinks deep into that whole wretched, morally decadent world which all the arts of the Renaissance could only gloss over with an artificial sheen of beauty $-a$ world in which heroes could no longer exist, but which was merely the predestined prey of the brutal soldier, Fortinbras." Is it not possible that Wagner mistook the character of Fortinbras and the true inwardness of this personage?

How realougly and intimately Wagner studied Shakespeare is also evidenced by a passage in a letter to Mathilde Wesendonk (Letter 97): "Over Shakespeare .... I again had to laugh long, and this brought me round to my favorite theme, our intercourse with the great, which is, after all, our best way of getting even with the world. That marvelous waggish smile of Shakespeare's! That divine cynicism! In very truth, man can no higher strive out of his wretchedness; no Genius can do more-only a Saint."

Concerning Wagner's Shakespeare readings we possess the further testimony of Malvida von Meysenbug ("Lebensabend einer Idealistin") and of Kietz, the sculptor ("Erinnerungen"). The latter writes: "After supper he fetched 'Hamlet' and read the 
first half; I shall never forget that evening. It was the first time that I had heard him read a poem by Shakespeare; he read quite without pathos, but most effectively and in good taste. In certain places he interrupted the reading in order to make comments." And, in like vein, Miss von Meysenbug: "His Shakespeare readings were delightful beyond description; one felt as if one fully comprehended the great dramatist for the first time, and I once told him jestingly that he had mistaken his profession-that he ought to have become an actor, in order to enact Shakespeare and make people realize to the full the imposing grandeur of his genjus."

Indeed, Wagner held Shakespeare to be the "greatest poet of all times"; 1 that he, alongside of the Attic tragedians, had, "as a second creator, revealed to us the boundless treasures of human nature."'

Wagner speaks of Shakespeare at greatest length in his Beethoven sketch, where he mentions the poet as the only man who, in his totality, can be considered an analogue to Beethoven:

This tremendous dramatist was really not to be understood by andogy with any poet whatsoever, and for this reason any eothetic judgment passed on him lecks a solid foundation. His dramias stand out as such an immediate likeness of the world, that the creative artist's agency in the presentation of the idea wholly escapes observation and, a fortiori, cannot be demonstrated; wherefore this presentation, admired as the product of superhuman genius, has been studied by our great poets, much as if it were a natural phenomenon, in order to discover the lawe of its creation.

Shakespeare was, according to Wagner, "a Beethoven who, awake, still dreams on"- a strange simile, explicable only from Wagner's childhood experiences (as detailed at the outset of this essay).

Between Shakespeare and Beethoven, Wagner perceives a "primitive affinity" whose correct characterization can be found only when sought for, not as between the musician and the poet, but as between the former and the poetic actor. That is, the secret lies in the immediacy of the presentation-for the musician, through living tones, for the actor, through mien and gesture:

As the drama does not describe humen perwonages, but lets them present themselves directly, music in its motives similarly brings before us the character of world-phenomena in their most intimate seity. The movement, configuration and variation of these motives are, to puraue the

2"Ober Schenopider und Sunger," Friting, Vol. IX, p. 160 (I alwaya quoto from the Third Edition).

r'Zunat und Revolution," Vol. III, p. 28 a m. 
analogy, not simply related to the drams, but the drama presenting the idea can, in reality, be fully and clearly comprehended only through the movements, shapes and changes of these motives of the music. . . . Hence, if we gather together the complex of Shakespeare's cosmos of human ahapes, with the uncommon significance of the contrasted characters therein contained, into a total impression upon our inmost sense, and compare it with the similar complex of Beethoven's cosmos of motives, with their imperatively penetrating and positive quality, one must become aware that the one microcosm is the full equivalent of the other, each being contained in the other, although they apparently move in wholly different spheres.

In proof of the above, Wagner incorrectly cites Beethoven's Coliolanus Overture, which he thinks was written to Shakespeare's tragedy, whereas, in reality, it was composed for a feeble drama by the Vienna writer Heinrich oon Collin. To be sure, it is possible that Wogner was acquainted with this fact, but assumed, nevertheless, that Beethoven had allowed himself to be influenced by Shakespeare's drama, which, in view of his predilection for the British poet, he had very likely read at one time or another.

Finally, Wagner very boldly proclaims his own work in the realm of art to be a kind of synthesis of the Shakespeare dramas with the symphonic. art of Beethoven-as the "most complete art-form" and "most complete drama," which "must be something far beyond the scope of poetry properly so-called." "This would be, at the same time, the sole art-form thoroughly responsive to the German spirit-a new art-form created by that spirit, at once purely human and its very own, which hitherto has been wanting in the modern world as contrasted with the ancient."

Can it be that Wagner, with this pet idea of his, placed too high an estimate on his "Art-work of the Future"? I raise this question at the close, without caring to answer it. For we do not yet know positively whether Ben Johnson's prophecy concerning Shakespeare is equally applicable to Wagner: He was not of an age, but for all time.

(Trandatad by Theodoro Bakor.) 